\title{
Pengaruh Persentase Serat Sabut Pinang terhadap Sifat Fisik dan Mekanik Papan Beton Resin Epoksi
}

\author{
Ira Febri Winda*, Alimin Mahyudin \\ Laboratorium Fisika Material \\ Fakultas Matematika dan Ilmu Pengetahuan Alam Universitas Andalas \\ Kampus Unand Limau Manih, Padang, 25163, Indonesia \\ *irafebriwinda20@gmail.com
}

\begin{abstract}
ABSTRAK
Telah dilakukan penelitian tentang pengaruh persentase serat sabut pinang dan resin epoksi terhadap sifat fisik dan mekanik papan beton. Papan beton dibuat dengan variasi sampel serat sabut pinang yaitu $0 \%$; $0,2 \% ; 0,4 \% ; 0,6 \% ; 0,8 \%$ terhadap volume cetakan. Sifat fisik dan mekanik yang diuji meliputi densitas, porositas, daya serap air dan kuat tekan dengan sampel berukuran 5 x 5 x $1 \mathrm{~cm}$, sedangkan kuat lentur dengan sampel berukuran $20 \times 5 \times 1 \mathrm{~cm}$. Kuat tekan dan kuat lentur diuji menggunakan universal testing machine (UTM) sedangkan densitas, porositas dan daya serap air dikarakterisasi menggunakan neraca digital. Nilai kuat tekan dan kuat lentur paling tinggi didapat pada persentase serat $0,6 \%$. Densitas yang paling rendah terdapat pada persentase serat $0,8 \%$, sedangkan daya serap air paling tinggi terdapat pada persentase serat $0,8 \%$. Berdasarkan hasil penelitian kuat tekan sudah mendekati standar SNI-03-34492002, kuat lentur sudah memenuhi standar SNI 03-3449-2002, densitas sudah memenuhi standar ISO 8335-1987, sedangkan daya serap air dan porositas belum memenuhi standar SNI 03-2105-2006.

Kata kunci : papan beton, resin epoksi, kuat tekan, kuat lentur, densitas dan daya serap air.
\end{abstract}

\section{ABSTRACT}

The effect of the percentage of areca fiber and epoxy resin on physical and mechanical properties of concrete board had been investigated. Concrete boards were made by varying the ratio of areca fiber to 0\%; 0.2\%; 0.4\%; 0.6\%; 0.8\% againts the printed volume. The sample physical and mechanical properties that were measered included density, porosity, water absorption and compressive strength with for sample size of $5 \times 5 \times 1 \mathrm{~cm}$, while $20 \times 5 \times 1 \mathrm{~cm}$ for flexural strength. Compressive strength and flexured strength we tested using universal testing machine (UTM). The highest value of compressive strength andflexured strength is obtained at $0.6 \%$ fiber percentage. The lowest density is found in the percentage of $0.8 \%$ fiber, while the highest water absorption is present in $0.8 \%$ fiber percentage. Based on the results of research, the compressive strength has been close to SNI 03-3449-2002 standard, the bending strength has fulfilled the standard of SNI 03-3449-2002, the density has fulfilled the standard of ISO 8335-1987, while the water absorption and porosity have not fulfilled the standard of SNI 03-21052006.

Keywords: concrete board, epoxy resin, compressive strength, flexural strength, density and water absorption.

\section{PENDAHULUAN}

Material komposit merupakan paduan dari dua atau lebih material penyusun, memiliki sifat baru yang berbeda dengan sifat material penyusunnya. Masing-masing material penyusunnya tetap terpisah dan dapat dibedakan pada skala makroskopik. Material komposit digunakan pada berbagai macam produk, seperti bangunan, jembatan, plafon, planel dinding, partisi ruang dan lain sebagainya.

Material komposit terdiri dari matriks dan filler (pengisi). Filler berdasarkan sumbernya terbagi atas bahan alami dan bahan sintesis. Bahan alami adalah bahan yang berasal dari tumbuhan seperti serat batang bambu (Putririani, 2009), serat ijuk (Trisna dan Mahyudin, 2012), serat daun nanas (Sriwita dan Astuti, 2013), serat eceng gondok (Qarina dkk, 2016), serat sabut kelapa (Bose dan Meera, 2017), dan lain sebagainya. Bahan sintesis adalah bahan yang berasal dari pabrik contohnya seperti serat gelas, karbon dan kevlar (Schwartz, 1984). Bahan alam (filler) memiliki keunggulan dibandingkan bahan sintesis yaitu mampu diregenerasi untuk mengantisipasi bahan sintetis yang dipengaruhi oleh sumber minyak bumi yang tidak bisa diperbaharui.

Juwairiah (2009) telah melakukan penelitian tentang efek komposisi agregat batu apung dan resin epoksi dalam pembuatan semen polimer terhadap karakteristiknya. Hasil yang didapat 
menunjukan peningkatan pada $25 \%$ resin epoksi dengan nilai kuat tekan beton sebesar 31,2 Mpa dan kuat tarik sebesar 8,27 Mpa.

Metode penyusun serat sabut pinang yang telah dilakukan Olanda dan Mahyudin (2013) menggunakan satu lapis dengan teratur yang diletakan diantara matriks, dengan variasi persentase serat terhadap massa adonan serat, semen, gipsum dan air yang digunakan adalah $0 \% ; 0,2 \% ; 0,4 \% ; 0,6 \% ; 0,8 \%$. Dari hasil pengujian didapatkan nilai kuat tekan dan kuat lentur paling tinggi pada persentase serat $0,6 \%$, sedangkan daya serap air diperoleh pada persentase serat $0,8 \%$.

Sifat fisik dan mekanik papan gipsum-beton serat sabut pinang (Silvia dkk, 2017) menghasilkan daya serap air terendah sebesar $23,51 \%$ dan kuat lentur terendah yaitu sebesar $1,944 \mathrm{~kg} / \mathrm{cm}^{2}$, hal ini disebabkan oleh tidak adanya penambahan resin epoksi pada sampel yang dapat meningkatkan kekuatan sampel. Pada penelitian ini telah dilakukan "pengaruh persentase serat sabut pinang dan resin epoksi terhadap sifat fisik dan mekanik papan beton". Pemilihan serat sabut pinang didasari oleh seratnya yang tipis dan pendek sehingga mudah diatur. Serat sabut pinang dipilih berdasarkan kandungan kimianya yang memiliki lignin dan selulosa, dimana secara alami dapat mengalami penguraian dalam waktu relatif lama oleh mikroba (tahan lama, tidak mudah busuk/rusak). Serat ini juga memiliki sifat fisis dapat menyerap air sehingga sangat bagus digunakan untuk bahan campuran papan beton yang diperkirakan dapat mempersingkat waktu pengeringan/kematangan papan (Ladislaus, 2014).

Disamping dengan penambahan serat sabut pinang dalam pembuatan papan beton dapat juga ditambah dengan bahan lain agar kualitasnya dapat ditingkatkan. Bahan tersebut berupa resin polimer. Bahan polimer yang ditambahkan pada papan beton mampu menutup ronggarongga pada papan beton lebih rapat agar tahan kelembaban tinggi. Resin polimer yang dipakai pada penelitian ini adalah resin epoksi (Blaga dan Beaudion, 1985).

Resin yang digunakan dalam penelitian ini adalah resin bening yang dijual di pasaran yang biasanya digunakan dalam membuat kerajinan tangan. Resin ini termasuk jenis resin epoksi yaitu suatu kopolimer yang terbentuk dari dua bahan kimia yang berbeda dimana bahan satu berperan sebagai "resin" dan bahan yang lain berperan sebagai "pengeras" (Juwairiah, 2009).

\section{METODE}

Pembuatan komposit papan beton serta pengujian daya serap air, densitas dan porositas dilaksanakan di Laboratorium Fisika Material Jurusan Fisika Universitas Andalas. Pengujian kuat tekan dan kuat lentur dilakukan di Laboratorium Mekanik Politeknik Negeri Padang. Bahan yang digunakan dalam penelitian ini adalah serat sabut pinang yang berguna sebagai penguat ikatan matrik yang panjangnya $3 \mathrm{~cm}$ dengan variasi serat $0 \%, 0,2 \%, 0,4 \%, 0,6 \%, 0,8 \%$ dan variasi resin $0 \%, 0,25 \%, 0,5 \%, 0,75 \%, 1 \%$. Bahan matriks yang digunakan adalah semen, pasir, air dan air. Papan beton yang dibuat berukuran $5 \times 5 \times 1 \mathrm{~cm}^{3}$ untuk pengujian densitas, daya serap air, porositas dan kuat tekan. Pengujian kuat lentur dilakukan pada sampel dengan ukuran 20 × 5 x $1 \mathrm{~cm}^{3}$.

Pemisahan serat sabut pinang dilakukan secara tradisional meliputi perendaman dan pemisahan serat. Serat direndam dengan larutan alkali $5 \% \mathrm{NaOH}$ selama 2 jam. Kemudian serat sabut pinang dibilas dengan air untuk menghilangkan kandungan $\mathrm{NaOH}$ yang tersisa. Setelah itu serat sabut pinang dikeringkan dengan oven bersuhu $\pm 40{ }^{\circ} \mathrm{C}$ selama 2 jam untuk meghilangkan kadar air yang tersisa. Selanjutnya serat sabut pinang dipotong sepanjang $3 \mathrm{~cm}$.

Tahap pertama adalah pembuatan pasta beton dengan mencampurkan semen dan pasir dalam wadah hingga warnanya sama. Setelah tercampur rata, tambahkan air sedikit demi sedikit, dan kemudian aduk hingga merata. Aluminium pasta dan resin dicampur kedalam adukan pasta beton. Papan beton kemudian dituangkan ke dalam cetakan dengan ukuran $20 \mathrm{~cm}$ x $5 \mathrm{~cm}$ x $1 \mathrm{~cm}$ untuk uji kuat lentur, sedangkan untuk uji daya serap air, densitas dan porositas serta kuat tekan digunakan cetakan berukuran $5 \mathrm{~cm}$ x $5 \mathrm{~cm}$ x $1 \mathrm{~cm}$. Serat disusun dengan arah two dimensional reinforcement dan kemudian dituangkan lagi pasta beton. Permukaan sampel diratakan dengan sendok semen dan didiamkan dalam cetakan selama 24 jam. Setelah itu sampel uji yang terbentuk dikondisikan pada suhu ruangan selama 28 hari sebelum digunakan untuk pengujian sesuai standar. 


\subsection{Pengujian Uji Kuat Lentur}

Pengujian kuat lentur dilakukan dengan menggunakan UTM untuk mengetahui ketahanan atau batas hancur sampel uji. Pengujian dilakukan dengan meletakkan sampel uji pada tempat sampel. Kemudian, diberikan pembebanan di atas sampel uji bagian tengah sampel. Nilai beban maksimum dan jarak yang tertera pada mesin uji dicatat saat benda mengalami lendutan. Pengujian dilakukan sebanyak 5 kali untuk setiap komposisi sampel. Nilai kuat lentur $\left(f_{r}\right)$ dihitung dengan Persamaan 1.

$$
f_{r}=\frac{3 P L}{2 b d^{2}}
$$

dengan $f_{r}$ adalah kuat lentur $\left(\mathrm{kg} / \mathrm{cm}^{2}\right), P$ adalah tebal rata-rata benda uji $(\mathrm{cm}), L$ adalah lebar rata-rata benda uji $(\mathrm{cm}), b$ adalah beban patah maksimum $(\mathrm{kg}), d$ adalah jarak tumpuan $(\mathrm{cm})$.

\subsection{Pengujian Uji Kuat Tekan}

Pengujian kuat tekan dilakukan dengan meletakkan sampel uji pada tempat sampel. kemudian diberikan pembebanan di atas sampel uji pada permukaan sampel. Skala yang tertera pada mesin uji saat benda uji mengalami keretakan dicatat sebagai nilai beban maksimum. Pengujian dilakukan sebanyak 5 kali untuk setiap komposisi sampel. Nilai kuat tekan $F_{c}$ dapat dihitung dengan Persamaan 2.

$$
f_{c}=\frac{P}{A}
$$

dengan, $f_{c}$ adalah kuat tekan $\left(\mathrm{kg} / \mathrm{cm}^{2}\right), P$ adalah beban maksimum $(\mathrm{kg}), A$ adalah luas bidang permukaan $\left(\mathrm{cm}^{2}\right)$.

\subsection{Pengujian Densitas}

Pengujian densitas sampel uji dilakukan pada kondisi kering. Mula-mula panjang, lebar dan tebal sampel uji diukur menggunakan jangka sorong. Kemudian, sampel uji ditimbang menggunakan neraca digital dan hasilnya dicatat sebagai $m$. Nilai densitas sampel uji dihitung menggunakan Persamaan 3.

$$
\rho=\frac{m}{V}
$$

dengan, $\rho$ adalah densitas $\left(\mathrm{g} / \mathrm{cm}^{3}\right), m$ adalah massa $(\mathrm{g}), V$ adalah volume $\left(\mathrm{cm}^{3}\right)$.

\subsection{Pengujian Daya Serap Air}

Mula-mula sampel uji direndam pada suhu ruang selama 24 jam. Lalu sampel uji diangkat dan diseka dengan kain hingga airnya tidak menetes lagi. Kemudian sampel uji ditimbang menggunakan neraca digital dan dicatat hasilnya sebagai $m_{b}$. Setelah itu, nilai daya serap air dihitung menggunakan Persamaan 4.

$$
\text { daya serap air } \%=\frac{\mathrm{mb}-\mathrm{m}}{\mathrm{m}} 100 \%
$$

dengan, mb adalah massa basah (g), m adalah massa kering (g).

\subsection{Pengujian Porositas}

Pengujian porositas dilakukan bersamaan dengan pengujian daya serap air. Perhitungan porositas sampel uji menggunakan Persamaan 5.

$$
\text { porositas } \%=\frac{m b-m}{v} \frac{1}{\rho_{\alpha}} 100 \%
$$

dengan, $m b$ adalah massa basah $(\mathrm{g}), m$ adalah massa kering $(\mathrm{g}), V$ adalah volume $(\mathrm{cm} 3), \rho_{\alpha}$ adalah massa jenis air $\left(\mathrm{g} / \mathrm{cm}^{3}\right)$. 


\section{HASIL DAN DISKUSI}

\subsection{Densitas}

Gambar 1 menunjukan pengaruh persentase serat sabut pinang terhadap densitas papan beton. Sampel tanpa serat sabut pinang (persentase $0 \%$ ) memiliki nilai densitas yang paling tinggi yaitu $1,93 \mathrm{~g} / \mathrm{cm}^{3}$. Densitas antara persentase serat $0 \%$ dan $0,2 \%$ tidak jauh berbeda, yaitu sekitar $0,01 \mathrm{~g} / \mathrm{cm}^{3}$. Ini disebabkan karna sedikitnya serat dalam papan beton. Densitas terendah terlihat pada papan beton pada persentase $0,8 \%$ yaitu $1,80 \mathrm{~g} / \mathrm{cm}^{3}$. Densitas yang rendah disebabkan oleh adanya rongga udara pada lapisan matriks. Jumlah rongga udara pada papan beton sebanding dengan massa serat sabut pinang yang digunakan (Sihombing, 2000).

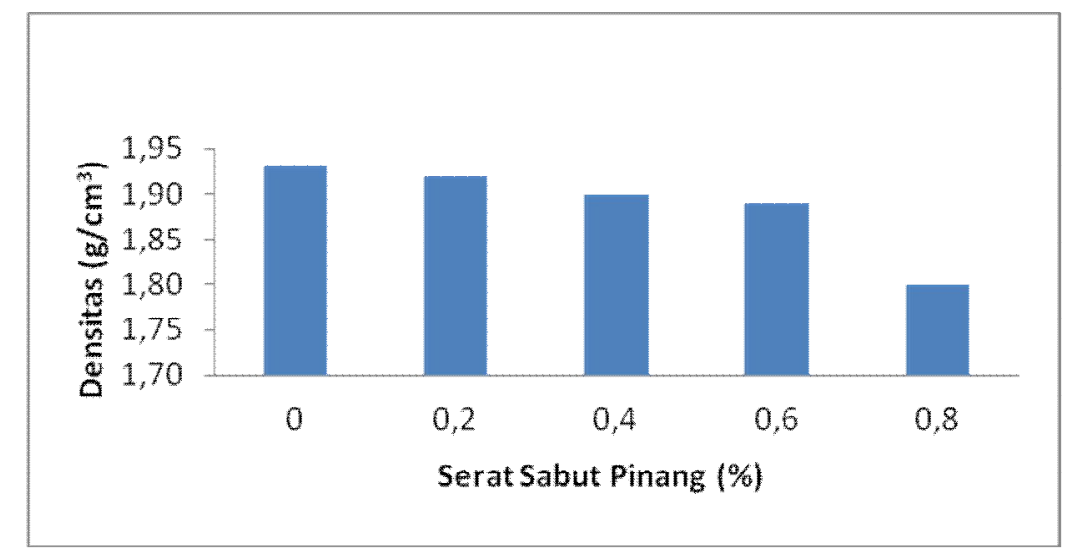

Gambar 1 Pengaruh persentase serat sabut pinang terhadap densitas papan beton

\subsection{Daya Serap Air}

Gambar 2 menunjukan pengaruh persentase serat sabut pinang terhadap daya serap air papan beton. Sampel tanpa serat (persentase 0\%) sebesar 9,42\%. Persentase serat 0,2\% daya serap airnya mengalami peningkatan manjadi $13,59 \%$. Pada persentase $0,4 \%$ daya serap air terus meningkat menjadi $13,79 \%$. Daya serap air paling tinggi didapat pada persentase serat $0,8 \%$ yaitu $19,28 \%$. Daya serap air terendah ditunjukan pada persentase serat $0 \%$. Hal ini disebabkan pada persentase ini papan beton yang dicetak tidak memiliki kandungan serat sehingga terdapat rongga-rongga udara yang sedikit.

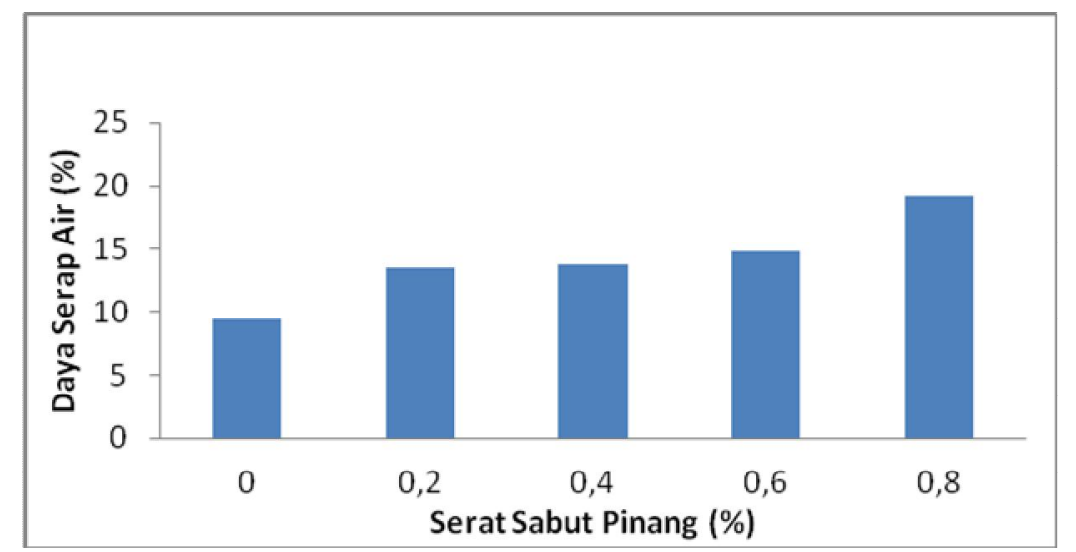

Gambar 2 Pengaruh persentase serat sabut pinang terhadap daya serap air papan beton

\subsection{Porositas}

Gambar 3 menunjukan pengaruh persentase serat sabut pinang terhadap porositas papan beton. Sampel tanpa serat (persentase 0\%) sebesar 19,94\%. Persentase 0,2\% porositas mengalami peningkatan sebesar $26,05 \%$. Pada persentase $0,4 \%$ porositas terus meningkat manjadi $26,23 \%$. Porositas paling tinggi di dapat pada persentase $0,8 \%$ yaitu $34,59 \%$. Hal ini disebabkan karna banyaknya rongga-rongga udara pada papan beton. 


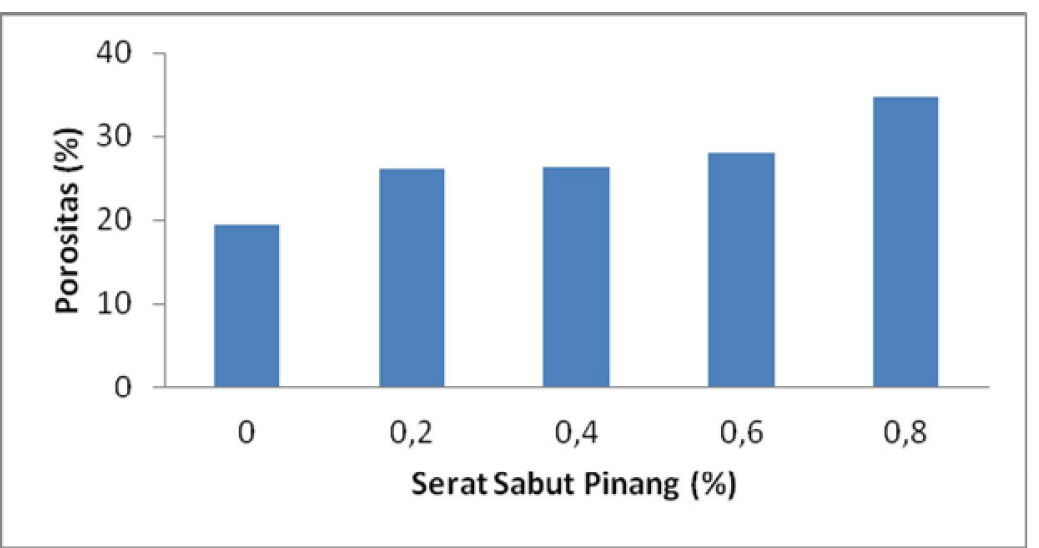

Gambar 3 Pengaruh persentase serat sabut pinang terhadap porositas papan beton

\subsection{Kuat Tekan}

Gambar 4 menunjukan pengaruh persentase serat sabut pinang terhadap kuat tekan papan beton. Kuat tekan terendah terdapat pada persentase $0 \%$ karena tidak ada serat yang akan memperkuat ikatan matriks . Dalam persentase $0,2 \%$ serat didapatkan kuat tekan yang masih kecil. Nilai tertinggi kuat tekan papan beton berserat sabut pinang diperoleh pada persentase $0,6 \%$ degan nilai $45,8 \mathrm{~kg} / \mathrm{cm}^{2}$. Adanya nilai tertinggi ini disebabkan oleh serat sabut pinang memiliki kemampuan memperkuat ikatan matriks menjadi sempurna karena adanya selulosa serat, namun selulosa serat hanya bekerja baik pada kadar tertentu yaitu pada persentase serat $0,6 \%$. Serat sabut pinang yang ditambahkan secara berlebihan akan membuat selulosa serat tidak akan bekerja pada titik tertiinggi sehingga papan beton yang dihasilkan mengalami penurunan nilai kuat tekan (Sihombing, 2000).

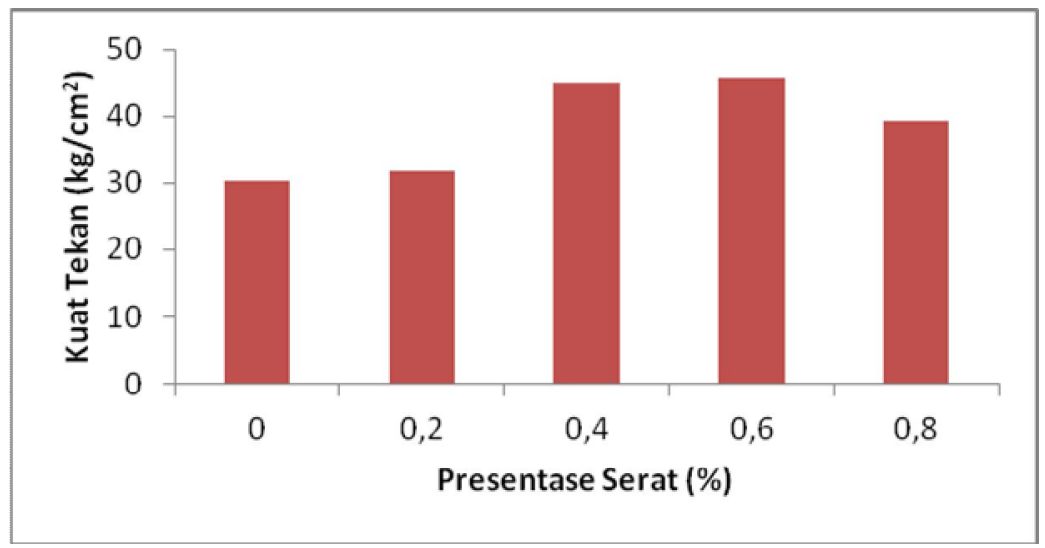

Gambar 4 Pengaruh persentase serat sabut pinang terhadap kuat tekan papan beton

\subsection{Kuat Lentur}

Gambar 5 menunjukan pengaruh persentase serat sabut pinang terhadap kuat lentur papan beton. Kuat lentur terendah terdapat pada persentase serat $0 \%$ sebesar $42,6 \mathrm{~kg} / \mathrm{cm}^{2}$. Pada persentase serat $0,2 \%$ kuat lentur terus mengalami peningkatan dengan nilai $56,7 \mathrm{~kg} / \mathrm{cm}^{2}$. Kuat lentur tertinggi didapatkan pada persentase serat $0,6 \%$ sebesar $71,1 \mathrm{~kg} / \mathrm{cm}^{2}$.

Berdasarkan Gambar 5 hasil kuat lentur pada tiap variasi persentase serat sabut pinang pada papan beton didapatkan nilai yang berbeda-beda. Hal ini membuktikan bahwa penambahan komposisi penguat akan berpengaruh terhadap kelenturannya. Namun tidak dapat disimpulkan bahwa semakin banyak serat yang ditambahkan maka kuat lentur papan beton akan semakin baik. Penambahan serat yang berlebihan akan membuat papan memiliki kekuatan penahan yang kecil dan mudah patah (Sihombing, 2000). Nilai kuat lentur tertinggi didapat dengan persentase komposisi tertentu yaitu pada persentase serat $0,6 \%$.

Kuat lentur terendah terdapat pada persentase serat $0 \%$, ini disebabakan karena tidak ada serat sebagai filler. Serat ini yang berfungsi untuk menahan beban yang diberikan dan 
membuat papan memiliki kelenturan, sehingga bila serat tidak ada maka beban hanya akan diteruskan sehingga papan patah tanpa papan mengalami kelenturan.

Dalam persentase serat $0,6 \%$ diperoleh nilai tertinggi kuat lentur papan beton. Serat sabut pinang mampu menahan deformasi yang terjadi ketika diberikan beban kepada matriks. Hal ini dikarenakan panambahan massa serat menyebabkan ikatan antar matriks beton yang dihasilkan semakin kuat. Namun penambahan serat sabut pinang yang berlebihan akan membuat nilai kuat lentur papan beton menurun, seperti yang terlihat pada persentase serat $0,8 \%$ nilai kuat lentur yang didapat lebih kecil dari persentase serat $0,6 \%$. Saat diuji papan beton berserat $0,8 \%$ lebih mudah patah. Hal ini disebabkan oleh komposisi matriks dan filler memiliki nilai tertinggi. Nilai tertinggi yang didapat pada persentase serat $0,6 \%$ dengan nilai $71,1 \mathrm{~kg} / \mathrm{cm}^{2}$.

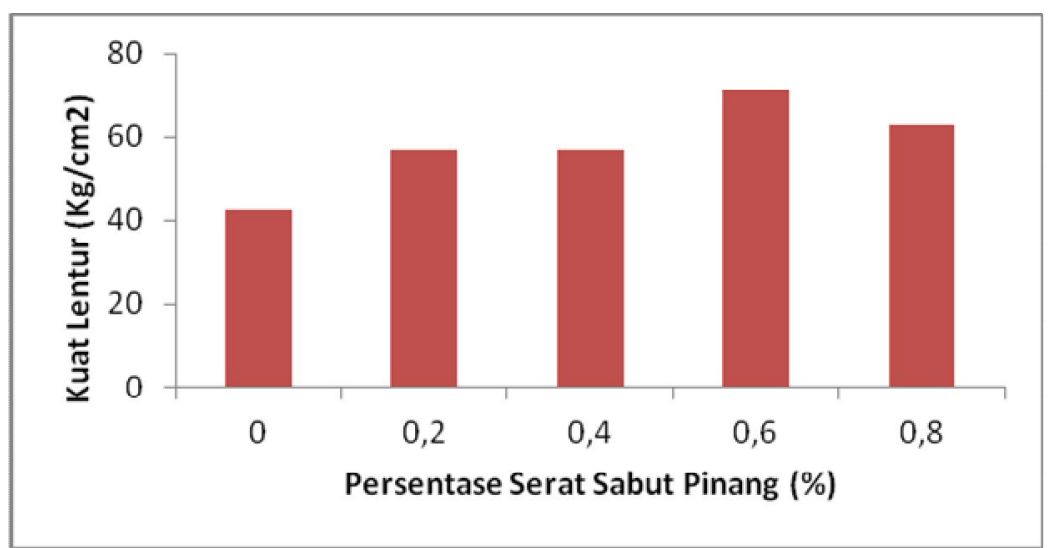

Gambar 5 Pengaruh persentase serat sabut pinang terhadap kuat lentur papan beton

\section{KESIMPULAN}

Kuat tekan dan kuat lentur memiliki nilai tertinggi pada persentase serat $0,6 \%$. Densitas terendah didapatkan pada persentase serat $0,8 \%$. Daya serap air dan porositas memiliki nilai terendah pada persentase serat 0\%. Standar mutu yang digunakan yaitu SNI 03-2105-2006, ISO 8335-1987, SNI 03-3449-2002 dan SNI 03-2104-1991. Kuat tekan belum memenuhi standar SNI-03-3449-2002 dengan nilai $>68 \mathrm{~kg} / \mathrm{cm}^{2}$, kuat lentur sudah memenuhi standar SNI 03-34492002 dengan nilai $>17 \mathrm{~kg} / \mathrm{cm}^{2}$. Densitas sudah memenuhi standar ISO 8335-1987 dengan nilai $>1,0 \mathrm{~g} / \mathrm{cm}^{3}$, daya serap air dan porositas belum memenuhi standar SNI 03-2105-2006 dengan nilai $14 \%$ dan $25 \%$.

\section{DAFTAR PUSTAKA}

Blaga, A. dan J.J. Beaudion, Polymer Concrete (Canadian Building Digest, Calgary, 1985), hal. 242.

Bose, S., dan Meera ,C.M., Structural Bahaviour of Laterally Loaded Plain and Fibre Reinforced Precast Foamde Concrete Sandwich Panels. 5, 1-24 (2017).

Juwairiah., "Efek Komposisi Agregat Batu Apung dan Resin Epoksi Dalam Pembuatan Semen Polimer Terhadap Karakteristiknya", Tesis S2, Universitas Sumatera Utara, 2009.

Ladislaus, W.N, "Melt Processed Polymer Composition Derived From Leaf Sheaths of Tress The Genus Arecaceae" (International Application, 2014) hal. 1-14.

Olanda, S., dan Mahyudin, A., Jurnal Fisika Unand. 2, 94-100 (2013).

Putririani, R., "Pengaruh Isian Mortar Terhadap Kuat Kuat Lentur Bambu", Skripsi S1, Universitas Negeri Semarang, 2009.

Qarina, U., Mahyudin, S., dan Handani, S., Jurnal Fisika Unand. 5, 233-237 (2016).

Schwartz, M., Composite material handbook (Mc Graw Hill, New York, 1984), hal. 162-184.

Siagian, S.P., Administrasi Pembangunan (Haji Masagung, Jakarta, 2012), hal. 36-45.

Sihombing, T., Pinang Budidaya dan Prospek Bisnis (Penebar Swadaya, Jakarta, 2000), hal. 7078.

Silvia, Y., Mahyudin, A., dan Handani, S., Jurnal Fisika Unand. 6, 188-193 (2017).

Sriwita, D., dan Astuti., Jurnal Fisika Unand. 3, 30-36 (2013).

Trisna, H., dan Mahyudin, S., Jurnal Fisika Unand. 1, 30-36 (2012). 